\title{
Exploring the Effectiveness of Using Big Books in Teaching Primary English in Malaysian Classrooms
}

\author{
AIZAN YAACOB \\ Universiti Utara Malaysia \\ ANNAMARIA PINTER \\ University of Warwick, $U K$
}

\begin{abstract}
There are many benefits of using stories for language and literacy development particularly in the areas of vocabulary (Cameron, 2001; Elley, 1989; Penno, Wilkinson \& Moore 2002; Hargrave \& Senechal, 2000) and reading comprehension. Yet, much is still unknown in second language (L2) contexts. This paper investigates the use of Big Books in primary English in Malaysia where English is taught as an official second language. It draws on transcript data from one teacher from one primary school to illustrate how students' active participation and interest in language learning emerged as the teacher introduced Big Books instead of the textbook. Our data shows that practice with Big Books changes the interaction patterns and learning opportunities. Students were actively involved and they contributed to the discussions and made spontaneous comments about the stories. Most importantly, the teacher's elicitation skill is essential in enhancing students' learning. The Ministry of Education's hopes to provide more active engagement and to increase students' interests and motivation through stories were achieved.
\end{abstract}

\section{INTRODUCTION}

In Malaysian classrooms, where English is taught as an official second language, the traditional whole class teacher-centred approach tends to predominate. For teaching reading, teachers adopt techniques of choral reading aloud with traditional drilling and repetition (Yaacob, 2006). The emphasis is placed on mastering students' pronunciation and spelling. Mistakes are corrected immediately and sentences 
are repeated several times to reinforce language. Such traditional practice can be seen in the following extracts which were recorded from the classroom of one teacher working with the textbook.

Extract 1. Textbook Lesson

\begin{tabular}{|rll|}
\hline & & $\begin{array}{l}\text { (Teacher writes the instructions from the text book on } \\
\text { the board and asks students to read) }\end{array}$ \\
1 & SS & STAND UP (Students read from the board) \\
2 & T & STAND UP \\
3 & SS & STAND UP \\
4 & T & SIT DOWN \\
5 & SS & SIT DOWN \\
6 & T & GO STRAIGHT \\
7 & SS & GO STRAIGHT \\
8 & T & GO STRAIGHT \\
9 & SS & GO STRAIGHT \\
10 & T & TURN RIGHT \\
11 & SS & TURN RIGHT \\
12 & T & TURN LEFT \\
13 & SS & TURN LEFT \\
\hline
\end{tabular}

Extract 2. Textbook Lesson

\begin{tabular}{|lll|}
\hline 17 & T & Ok spell stand \\
18 & SS & S.T.A.N.D. \\
19 & T & Up? \\
20 & SS & U.P. up \\
21 & T & STAND UP. Ok good. Spell sit \\
22 & SS & S.I.T. sit \\
23 & T & Down? \\
24 & SS & D.O.W.N. down \\
25 & T & SIT DOWN. Read properly SIT DOWN \\
26 & SS & SIT DOWN \\
27 & T & SIT DOWN \\
28 & SS & SIT DOWN \\
29 & T & Spell go \\
30 & SS & G.O. GO \\
31 & T & Straight? \\
32 & SS & S.T.R.A.I.G.H.T. STRAIGHT \\
33 & T & GO STRAIGHT \\
34 & SS & GO STRAIGHT \\
\hline
\end{tabular}


In the first extract, the teacher is working with directions from the textbook and she is asking students to read the phrases written on the board. She asks them to repeat each line several times. In the second extract she is asking the students to repeat the words again and spell them. Both extracts reflect what this teacher typically does when she works with the textbook.

This paper explores what happens to the same teacher and the learners when the traditional textbook is put away and replaced by Big Books, i.e. what observable difference Big Books make in terms of classroom interaction, student involvement and learning.

\section{THE MALAYSIAN CONTEXT}

In tandem with the country's aspirations to become a developed nation by 2020 and with an effort to improve teaching and learning situations, the Ministry of Education introduced innovative practices for primary classrooms including the English Hour, Big Books and CD-ROMs in 2002.

English Hour is a revised English Language Programme which was based on the model used in the UK "Literacy Hour" (Department of Education and Employment [DFEE], 1998). The new English Hour was proposed as a new structure for all English lessons. The daily English Hour comprises a four- step activity:

Step 1: Shared reading (15 minutes);

Step 2: Teaching points - pronunciation, spelling, wordattack skills (15 minutes);

Step 3: Guided Reading or writing and independent work (20 minutes) and;

Step 4: Summing up (10 minutes).

(Ministry of Education, 2002a, p. 23).

The focus of teaching in the English Hour is on developing language with story books. Teachers are encouraged to read with students every day during the shared reading session. The English Hour is hoped to provide active engagement and to produce high quality interaction:

Active engagement and high quality interaction means that the teacher and pupils are always talking to each 
other or discussing with each other about the ideas in the story or about spelling, grammar, pronunciation, etc.

(Ministry of Education, 2002b, p. 35).

In the context of the English Hour, Big Books were introduced to inculcate good reading habits among the students, while the CDROMs were hoped to provide greater opportunities to use English in an IT rich environment. The Big Books used in Malaysian classrooms are large size storybooks with simple story lines or sentences written at the bottom of the page of colourful pictures, and they are provided by the Ministry of Education.

This move towards the centrality of spoken interaction in learning reflects a major paradigm shift in teaching and learning in Malaysia. The new English language Syllabus in Malaysia (Ministry of Education, 2002a) also explicitly promotes meaningful and creative language practice in the English hour. Although drilling, repetition and reading aloud are mentioned in the syllabus guidelines, and they are perceived by teachers as 'effective' ways to maximize learning, the problem with these methods is that they are followed excessively and no time is left for more spontaneous or creative work (Yaacob, 2006). It is worthwhile to note that reading in the L1 (Bahasa Malaysia) is also conducted using a traditional method of drilling, repetition and reading aloud the syllables.

\section{INTERACTIVE READING ALOUD OF STORIES}

Stories are not only motivating and fun, but features of stories such as repeated patterns and rich vocabulary with interesting rhythm and sound effects are also stimulating and can create a natural support for language and literacy development (Bialystok, 2002). Many studies have provided evidence on the effect of listening to stories on children's vocabulary acquisition (Cameron, 2001; Elley, 1989; Penno et al., 2002; Hargrave \& Senechal, 2000) and reading comprehension (Rosenhouse, Feitelson, Kita \& Goldstein, 1997). It has also been suggested that stories could help develop positive attitudes towards language learning when children are actively involved.

Hargrave and Senechal (2000) examined the effect of storybook reading on the acquisition of vocabulary for preschool children (3-5) who had poor vocabulary skills. They compared 
the effects of regular shared reading (when children were passive participants) and dialogic reading (when they were actively involved) in the story reading session. Their study revealed that children with poor vocabulary skills learned new vocabulary in both conditions but in the dialogic reading session children made significantly better gains in language than did the children in the regular reading condition. This study suggests that it is important to actively engage children during shared reading sessions.

Another interesting study was conducted by Elley (1989) who investigated the phenomenon of incidental vocabulary learning through reading aloud sessions with 7 and 8 year old children. He hypothesized that children would learn the meanings of many new words that they heard in stories read aloud to them with or without any explanation to them. Thus, in his experiments, he compared reading with explanation of word meaning to reading without any explanation. The two experiments provided evidence that reading aloud to children is a significant source of vocabulary acquisition, and that teachers' additional explanations of words can double such gains. In addition to that, the experiments proved that the new learning is relatively permanent, and that children who scored low at the outset could gain at least as much as students who scored high. This study suggests that young children may learn new vocabulary incidentally when having illustrated storybooks read to them by a competent adult. In line with this, Penno et al. (2002) argued that, "although vocabulary learning occurred incidentally while listening to a story, students made greater vocabulary gains when the teacher provided an explanation in context of target vocabulary items" (p. 31).

Rosenhouse et al. (1997) on the other hand, conducted experiments to determine the effects of reading aloud to first graders in decoding, reading comprehension and picture storytelling, by comparing different types of literature and they discovered that exposure to any kind of reading enhances children's literacy and increases their skills in decoding, comprehension and picture storytelling. In addition to that, reading aloud sessions affect their "knowledge schemata" and the story structures, which are essential for reading comprehension. The more they are exposed to series of books, the better they understand the story structure and background information, and the more they enjoy them, the more they want to read them for pleasure. They claimed that "exposing beginning readers to read-aloud sessions in an early stage of reading acquisition 
improves their reading skills and enhances them to become leisure readers" (Rosenhouse et al., 1997, p. 180).

Apart from examining the effects of reading aloud of stories on vocabulary and comprehension, other studies have also looked at the children's expressive engagement during story reading by examining the questions children asked about pictures, story meaning and word meaning (Yaden, Smolkin \& Conlon, 1989). Interestingly, it appeared that learners asked more questions about pictures and story meaning rather than about word meaning. All these studies provided insights into the children's active involvement when listening to storybooks read to them.

In addition to benefits documented for L1 learning, storybook reading is also considered important in L2 by providing children with invaluable literacy experiences (Bialystok, 2002; Gregory, 1994; Cameron, 2001). Bialystok discusses the importance of oral language proficiency in learning to read in an L2 and suggests that "one aspect of oral competence that has repeatedly been shown to promote the acquisition of literacy is the command of literate language that follows from experience with early storybook reading" (2002, p. 165). In summary, previous studies have shown that reading aloud regularly to students at the primary school level, in the context of shared reading or recreational reading produces measurable and sometimes dramatic gains in reading, listening, and vocabulary.

Many studies have also provided evidence of the importance of adult-child interaction during storybook reading in the home (Heath, 1983; Heath \& Branscombe, 1986; Teale \& Sulzby, 1987; Campbell, 2001) and the school contexts (Penno et al., 2002; Elley, 1989; Brabham \& Lynch-Brown, 2002; Hargrave \& Senechal, 2000). As a matter of fact, the interaction between parent and child during book reading has been posited as one of the central vehicles by which young children acquire their first notions of the purposes of and elements involved in learning to read. This is true because on the one hand, parents are the child's first teachers as they spends most of their time with them, and on the other hand, "children, are not born knowing how to connect their knowledge and experience in "literate" ways to printed and pictorial texts. Rather, they must learn strategies for understanding texts just as they must learn the ways of eating and talking that are appropriate to their cultures or social groups" (Cochran- Smith, 1986, p. 36). Therefore it is crucial to have a competent adult to guide the child through the whole process of learning to read. 
One of the issues raised in most research on interactive storyreading between adult and children is the notion of 'mediation', which is found to be crucial for literacy development (Teale and Sulzby, 1987; DeBruin- Perecki, 2004). Researchers agree that the way the adult mediates the story to the child is more important than the total number of interactions between them. Teale and Sulzby (1987) for instance, argue that, "...the effect of being read to is not merely present or absent, or a quantitative issue. How the parent or teacher reads to the child the ways in which the literate text is mediated for the child is of great importance." (p. 116). According to Teale and Sulzby, storybook reading, like literacy itself is a cultural practice whereby two general questions are being addressed: who engages in the practice (and who does not), and how is the practice actually accomplished. The former question raised an issue of whether or not storybook reading is practised. This is important because in many instances, storybooks may be readily accessible in the homes or schools but they are not being read regularly to children. Arguably, in some instances, storybook reading may be considered marginal if compared to the teaching of reading and writing skills (Rooks, 1998; Bloch, 2000).

Another interesting study was conducted by Brabham and Lynch-Brown (2002) who examined three reading aloud styles that teachers could use: just reading, performance reading and interactional reading using experimental design, with an attempt to reveal statistical differences on vocabulary and comprehension for first and third graders. They discovered that interactional reading produced the greatest gains, while just reading produced the smallest gains in vocabulary and comprehension. They claimed that reading aloud is a powerful tool for enhancing the children's language and literacy development. This study also supported the notion that teacher's mediation and explanation are critical factors that benefit the children's learning of words, concepts, and construction of meaning in the early grades.

Wells (1985 cited in Williams and Gregory, 1999, p. 155) argues that the total interaction in which the story is embedded may also determine the child's success in school. He claimed that, "it is not the reading of stories on its own that leads children toward ...success in school but the total interaction in which the story is embedded. At first they need a competent adult to mediate as reader and writer between them and the text" (155). This notion is also supported by Debruin-Perecki (2004) who stated that, "it is primarily 
through interactive dialogue that children gain comprehension skills, increase their understandings of literacy conventions, and are encouraged to enjoy reading" (DeBruin- Perecki, 2004, p. 2). This line of research indicated that a competent adult plays an important role in preparing the child for later success in school. As a mediator, parents or teachers can support the children's learning by talking about the literacy conventions, pictures and story meaning, which can help to enhance their literacy development.

In summary, the literature suggests that reading aloud regularly to students at the primary school level, in the context of shared reading or recreational reading produces measurable and sometimes dramatic gains in reading, listening, and vocabulary. However, according to Elley (1989, p. 176) "few studies have attempted to demonstrate the specific language that children learn from listening to particular stories read aloud" and claimed that, "the research on story reading aloud is thin. Many studies on storybook reading were experimentally based and not conducted in the actual classroom context. Therefore, it can be argued that they fail to represent the actual interaction that takes place between the teacher and learners during storybook reading sessions. Besides, many of these studies examined children whose first language is English rather than looking at children whose first language is not English. This paper attempts to look at closely what happens in L2 classrooms where traditional textbooks are replaced by Big Books.

\section{METHODOLOGY}

This paper is part of a bigger project (Yaacob, 2006) which involved recording 48 English, Mathematics and Science lessons. Out of these, 26 English lessons by 4 teachers from 4 different schools in two districts of Kedah were analysed. Schools were chosen using purposive sampling with a sample that is fit for the purpose of the research (Arskey and Knight,1999; Flick, 2002). On average each teacher was recorded teaching 6 to 8 lessons. Within the 26 lessons, 5 were focused on Big Books, 4 were focused on CD-ROM materials, and 7 were devoted to the textbook while the rest were focused on sentences or words written on the board. From the 5 Big Book lessons, 4 were by one teacher. 
The methods used in the bigger project were observation, interview and children's role play. However, answers to the questions addressed in this article were drawn only from the classroom observation and interview which are described below.

\section{Classroom Observation}

Four primary schools in urban and rural areas in Kedah were visited and observations were recorded for twelve weeks. The observation was divided into two phases: observation cycle 1 and observation cycle 2 . In the observation cycle 1 , only classroom observations were made. However, during observation cycle 2, more observations, teachers and students interviews and students' role play were conducted. The researcher chose to adopt the role as 'participant observer'. One of the advantages of participant observation is that it provides a chance of seeing something unexpected, something which might have been overlooked before, which could be significant for the research.

Participant observation offers the advantage of serendipity: significant discoveries that were unanticipated. In contrast to the survey, which is planned on the basis of what the researcher expects to find, participant observation opens up possibilities for encountering the completely unexpected phenomenon that may be more significant than anything the field worker could have foreseen, suggesting important hypotheses worthy of further research" (Whyte, 1984, p. 27 cited in Richards, 2003, p. 110).

\section{Systematic Observation Schedule}

The second type of observation method used in the study was the systematic observation schedule. This systematic recording using time sampling recording system was devised and used alongside audio and video recordings to record the classroom events. Systematic observation contains "a systematic set of rules for recording and classifying classroom events" (Croll, 1986, p. 1) in an attempt to provide an accurate description of selected features of activities and interactions in the classroom. "Observation schedules help structure observations of talk, and are often used to record systematically the 
number and type of contributions made by different people" (Swann, 1994, p. 34).

\section{Interview}

Semi-structured interviews were conducted with the four teachers of Year 1 English, 8 groups of their students, and 2 State Education Officers. The semi-structured interviews were carried out along side the classroom observation to further investigate:

i. the teachers' perceptions of literacy events and practices in the English Hour,

ii. the students' perceptions of literacy learning and

iii. stakeholders' perceptions of the implementation of the English Hour.

The four teachers interviewed were all female teachers aged between $31-48$ years, with teaching experience ranging from 9 to 24 years. All of them graduated with either a certificate or a diploma from the teacher training colleges throughout Malaysia.

The findings described in this paper come from only one teacher. The data is analysed to illustrate how she changed her practice during her regular teaching depending on whether she was using the textbook or Big Books. This teacher was not trained in TESL but due to the shortage of English teachers in her rural area particularly in her school she was asked by the head teacher to teach English. There were 25 students aged 7 years old in her class and they had limited proficiency in the English language. More than half of the class was unable to read in English.

\section{FINDINGS}

\section{Big books improve students' participation and active learning}

In this lesson the teacher is using a Big Book called 'Stuck' (Jackman, 1998) which was about children playing around a tree house. In clear contrast to the traditional approach (See Extracts 1 and 2), in the following two extracts, we can see students initiating a discussion, asking questions and making spontaneous comments about the story. 


\begin{tabular}{|c|c|c|}
\hline 01 & $\mathrm{~T}$ & $\begin{array}{l}\text { Ok now what happen to them? All of them at the } \\
\text { top of the tree already. Look here please happy. } \\
\text { Ok. What happen to the dog and the rat? They are } \\
\text { chasing each other... }\end{array}$ \\
\hline 02 & S1 & $\{$ Rat ambik tulang $\operatorname{dog}<$ rat took the dog's bone $>$ \\
\hline 03 & $\mathrm{~T}$ & $\begin{array}{l}\text { Haa the rat take the bone. This bone belongs to the } \\
\text { dog. But the rat take it away. So the dog was very } \\
\text { angry. The dog chase the rat around the ... }\end{array}$ \\
\hline 04 & $\mathrm{~S} 2$ & Dia maroh ke? $<$ is the dog angry?> \\
\hline 05 & $\mathrm{~T}$ & $\begin{array}{l}\text { Ha <yes }>\text { around the tree there. Ok So what } \\
\text { happen? They knock all the boxes again. The } \\
\text { boxes fell down again. Ok. What happened? }\end{array}$ \\
\hline 06 & SS & HELP!! HELP!!!HELP!!! (ss read the text) \\
\hline 07 & $\mathrm{~T}$ & $\begin{array}{l}\text { Ha three of them they cannot come down they } \\
\text { called for... help }\end{array}$ \\
\hline 08 & SS & HELP! HELP! HELP! \\
\hline 09 & $\mathrm{~T}$ & $\begin{array}{l}\text { Ben asked for help. Rob asked for help! And Pen } \\
\text { asked for help. So they shouted HELP! }\end{array}$ \\
\hline 10 & $\mathrm{~T} \& \mathrm{SS}$ & HELP!! HELP!! HELP!! \\
\hline 11 & $\mathrm{~T}$ & Cried Pen and Rob \\
\hline 12 & $\mathrm{~T} \& \mathrm{SS}$ & $\begin{array}{l}\text { PEN AND ROB AND BEN (Teacher and } \\
\text { students read the text). }\end{array}$ \\
\hline 13 & $\mathrm{~T}$ & Three of them on the top of the tree. Can you see? \\
\hline 14 & SS & Yes \\
\hline 15 & S2 & $\begin{array}{l}\text { PEN AND ROB AND BEN (one student reads } \\
\text { from the book) }\end{array}$ \\
\hline 16 & $\mathrm{~T}$ & Where? Where's the rat? \\
\hline 17 & SS & $\begin{array}{l}\text { Ni!! < here!> (students pointed to the picture } \\
\text { excitedly) }\end{array}$ \\
\hline 18 & $\mathrm{~S}$ & $\begin{array}{l}\text { Nampak dia gelak <can you see it's laughing >. } \\
\text { Bird bird }\end{array}$ \\
\hline
\end{tabular}

In this episode, the teacher is explaining that the youngest boy, 'Ben' is stuck on the tree and his brother and his sister are trying to rescue him. In line 2 when she asks what happens to the children in the story when the dog is chasing the rat, one student explains that the rat takes the dog's bone. Furthermore, one learner initiates the question as illustrated in line 4, "Dia maroh ke?" $<I s$ the dog 
angry? $>$ and she manages to get the answer from the teacher (line 5). Students are also found to make comments freely regarding the story as indicated in lines 17 and 18 . This type of student-initiation is not usually found in traditional lessons observed.

Similarly, Extract 4 also shows students' initiation and active participation during another Big Book lesson which was about the 'The New Club Hut' (Jackman, 1998).

\section{Extract 4. The New Club Hut}

\begin{tabular}{|c|c|c|}
\hline 88 & $\mathrm{~T}$ & Shah! Zaid! Look here! What happened then? \\
\hline 89 & S & Bawak benda $<$ carried things $>$ \\
\hline 90 & $\mathrm{~T}$ & $\begin{array}{l}\text { Ha mum and dad helped them to make a hut. They } \\
\text { bring the planks they bring the tools the mat the } \\
\text { hammer they bring up to the tree. Rob brings the mat. } \\
\text { This one is the^ }\end{array}$ \\
\hline 91 & SS & The mat!! \\
\hline 92 & $\mathrm{~T}$ & $\begin{array}{l}\text { Ok and then what happened? Look (points to the } \\
\text { picture) }\end{array}$ \\
\hline 93 & S & $\begin{array}{l}\text { Wow! Hah jadi dah rumah dia (excited) < the house } \\
\text { is ready }>\end{array}$ \\
\hline 94 & $\mathrm{~T}$ & $\begin{array}{l}\text { Ha father built a hut on the tree. Can you see? Father } \\
\text { is holding a hammer ha look at mum also. Mum is also } \\
\text { holding a hammer. Now the house the hut is ready. } \\
\text { They bring up all the furniture table sofa put on the } \\
\text { curtains at the window ok? This one is the curtain. } \\
\text { What colour is the curtain? What colour is the curtain? }\end{array}$ \\
\hline
\end{tabular}

In this extract the teacher is explaining about the tools and equipment needed for the tree house and at this point students respond by saying that all the characters help by carrying things (line 89) to their new tree house. The teacher takes this further by describing in great detail the specific objects and tools shown in the picture. Students also volunteer the English word for some items such as, "mat" (line 91). In another example in line 93, a student provides a creative comment about the new tree house, "Wow! Hah jadi dah rumah dia (excited) < the house is ready> in response to the teacher's question. When L1 answers are given, the teacher does not translate them like in the traditional lesson as students can understand the meaning from the contextual clues in the story. 
Clearly, this example indicates that the Big Book story can get students actively involved and that they are not shy about making spontaneous comments about the story.

\section{Big Books increase students' interests and motivation}

In the following two extracts, we would like to illustrate how Big Books can create interest and motivation in children. Extract 5 is taken from the same story 'The New Club Hut' and this episode is extracted from the beginning of the lesson whereby the teacher is introducing the major characters.

\section{Extract 5. The New Club Hut}

\begin{tabular}{|lll|}
\hline 01 & S & PEN!! (a student shouts as the teacher opens the first \\
& & page) \\
02 & T & Pen. So what is the name of the big brother? \\
03 & SS & BOB! \\
04 & T & ROB (Teacher corrects) What is the name of the \\
& & smallest brother? \\
05 & SS & BEN!! \\
06 & T & Ben. Ok. Look here \\
07 & S & Ha ni lawa nya!!! $<$ ha this is beautiful $>$ \\
08 & T & Hmm. (agrees) \\
09 & SS & Tak nampak tak nampak $<$ can't see $>$ \\
10 & T & ok \\
11 & S & Teacher tak tinggi $<$ not high enough $>$ (teacher holds \\
& & the book higher)
\end{tabular}

In this extract the students are full of excitement and enthusiasm and as soon as the teacher opens the Big Book, one student shouts the name of the character as shown in line 01 . They manage to name the other characters as indicated in lines 03 and 05 . In the following line 07 , another student comments about the attractive picture on the page, "Ha ni lawa nya!!! < ha, this is beautiful>". This student's comment gets the other students excited as they stand up to get a better view of the picture while insisting that the teacher should hold the book higher (line 11). This episode shows that pictures and prints in the Big Book capture students' interest in the story. 
The following Extract 6 shows that students are motivated to read words from the page independently i.e. without the teacher's prompt. This is a continuation of the previous lesson from the same story, 'The New Club Hut'.

\section{Extract 6. The New Club Hut}

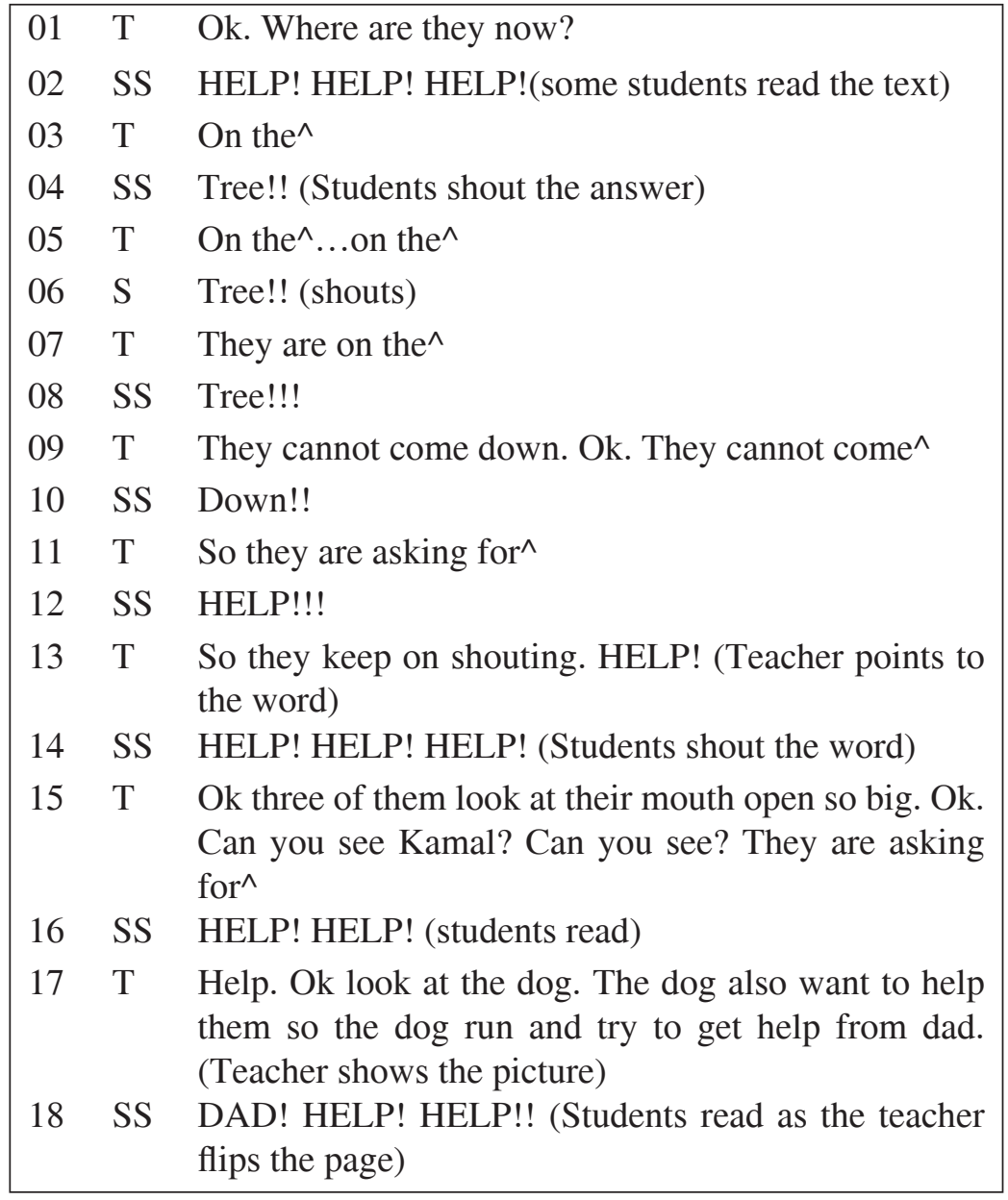

In this episode students shout out the answers most of the time and they read aloud the words in the Big Book as soon as the page is turned. In contrast to the traditional drilling and repetition, students read phrases without being prompted by the teacher, as can be seen in lines 02 and 18. In line 02 the teacher is showing a picture where all the three characters are stuck on the tree and 
shouting for help. When she asks where they are (line 01), instead of answering the teacher's question, the children read aloud the words, 'HELP! HELP! HELP!' (line 02) from the page. The large print and colorful illustrations attract their attention and motivate them to read the words by themselves. Similarly, in line 18, when the teacher flips the page, they immediately read "DAD HELP!" before the teacher explains what happens in the picture. This extract shows that students are able to produce more free utterances. One of the contributing factors to promote language learning is the teacher's elicitation skill. In this example the teacher has managed to elicit students' responses successfully.

\section{The teacher's own reflections}

When the teacher was interviewed about using these Big Books instead of following the textbook, she revealed that she started experimenting with them only very recently. She was afraid that she could not manage the classroom and students were not going to be interested in the story.

I was wondering how the students would react to the Big Book because I never tried it with my students before except that I have prepared the materials from a few books, photocopied and coloured them ..... I was afraid that I would not be able to control the class when I showed them the book and they would walk away or perhaps they would not be interested in the story because they had never seen one. In fact, I never took any storybook and never read to them. I never used anything except the textbook. Each of them had a textbook but for this one they had to give their full attention to me.

When questioned about the benefits and how she felt afterwards, the teacher commented that students enjoyed listening to the stories and that they increased their level of concentration and interest in language learning.

I really like the English Hour and telling stories to them. Year 1 students really like stories. When I tell them stories like the way I read to my children at home they listen with their mouths wide open. 
She explained that she received overwhelming responses from her students in that they asked for more stories every time she entered the classroom.

When I introduced the stories to them every time I entered the classroom they asked, "Teacher aren't you going to continue the story?", "Teacher don't you have another story?" The story I read to them was not finished and I haven't given them all the handouts, so they kept asking "Teacher don't you have stories?" (laughs). I told them, "Wait a minute, wait, we'll continue some other time."

\section{CONCLUSIONS AND IMPLICATIONS}

In this paper, we have attempted to show the pedagogical importance of using stories from Big Books in L2 classrooms. The lessons taught by this teacher were found to be meaningful for the students, the pictures in the Big Books were appealing, and the language was easy and readable. These features have increased the students' interests and motivation and better interaction patterns have been observed in the classroom. Not only did the teacher spend more time talking about the content and the characters of the stories than drilling and spelling words and phrases, she also managed to elicit students' responses. The teacher's elicitation skill is bound to be important to promote students' interaction. In this case, even though the teacher managed to ilicit responses from the students, her elicitation skills need to be improved. In some cases she played safe and her questions to the students were limited.

The data revealed that students were actively involved, they contributed to the discussion and made spontaneous comments as the teacher turned the pages. These were all positive developments in L2 learning in the given context. Our study supported earlier research on stories ( Yaden, Smolkin \& Conlon, 1989; DebruinPerecki, 2004). The teacher herself was also very positive about the Big Book experience and enjoyed the classes despite having little confidence to start with. For this teacher, when working with Big Books, the Ministry of Education's hopes to provide more active engagement and to increase students' interests and motivation to stories were achieved. However, the quality of interaction during storybook reading will have to be given more emphasis.

Although there are some difficulties with using Big Books such as lack of time, the pressure of exams (even for this age group!) 
and extra costs involved, our study indicates that the immediate benefits of working with these simple stories can be very satisfying for both teachers and learners.

This particular teacher had no special TESL/TEFL qualifications or experience with using stories in class and yet she has created excellent opportunities for children to learn and enjoy English. It is therefore logical to assume that if there were opportunities for teachers of English to participate in teacher development courses where they could share practices in relation to teaching with Big Books, many more classrooms would benefit.

While this article describes just one English teacher and her learners in Malaysia, we think that the results are applicable to ESL/ EFL teachers and learners in similar situations in other countries. Big Books may bring multiple benefits to primary English classes and teachers may want to experiment in their own contexts to try out their own ideas.

\section{NOTES}

\section{Transcription Conventions}

Bold - Bahasa Malaysia

Normal - English

Bold italic - dialect or non standard spelling

$<$ italic $>$ - English translation

( ) - non-verbal behaviour

(pause) - pause for a few seconds

CAPITAL LETTERS - reading from the text

XXX - unclear conversation

[ ] overlapping speeches

S.I.T. - spelling

$\wedge$ - prosodic cues

\section{REFERENCES}

Arskey, H., \& Knight, P. (1999). Interviewing for social scientists. London: Sage Publications.

Bialystok, E. (2002). Acquisition of literacy in bilingual children: A framework for research. Language Learning, 52(1), 159-199. 
Bloch, C. (2000). Don't expect a story: Young children's literacy learning in South Africa. Early Years, 20 (2).

Brabham, E. G., \& Lynch-Brown, C. (2002). Effects of teachers' reading aloud styles on vocabulary acquisition and comprehension of students in early elementary grades. Journal of Educational Psychology, 94(3), 465-473.

Cameron, L. (2001). Teaching languages to young learners. Cambridge: Cambridge University Press.

Campbell, R. (2001). Learning from interactive story-readings. Early Years, 21(2)

Cochran-Smith, M. (1986) Reading to children: A model for understanding texts. In Schieffelin, B.B. \& Gilmore, P. (Eds.). The acquisition of literacy: Ethnographic perspectives. Vol. XXI advances in discourse processes. New Jersey: Ablex Publishing Coronation.

Cohen, L., \& Manion, L. (1989). Research methods in education. London and New York: Routledge.

Croll, P. (1986). Systematic classroom observation. London: The Falmer Press.

DeBruin-Perecki, A. (2004). Assessing adult/child storybook reading practices. Retrieved from http://www.ciera.org/ library/reports/inquiry-2/2-004/2-004.html

Department for Education and Employment. (1998). Then National literacy strategy framework for teaching. London: DfEE.

Elley, W. B. (1989). Vocabulary acquisition from listening to stories. Reading Research Quarterly, XXIV(2), 174-187.

Flick, U. (2002). An introduction to qualitative research. London: Sage.

Gregory, E. (1994). Negotiation as a critical factor in learning to read in a second language. In D. Graddol, J. Maybin \& B. Stierer (Eds.), Researching language and literacy in social context. Multilingual Matters.

Hargrave, A. C., \& M. Senechal. (2000). A book reading intervention with preschool children who have limited vocabularies: The benefits of regular reading and dialogic Reading. Early Childhood Research Quarterly, 15(1), 75-90.

Heath, S. B. (1983). Ways with words. Cambridge: Cambridge University Press.

Heath, S. B., \& Branscombe, A. (1986). The book as narrative prop in language acquisition. In Schieffelin, B.B. \& Gilmore, P. (Eds.), The acquisition of literacy: Ethnographic perspectives, 
XXI advances in discourse processes. NJ: Ablex Publishing Corporation.

Hitchcock, G., \& Hughes, D. (1989). Research and the teacher: Qualitative introduction to school-based research. London and New York: Routledge Falmer.

Jackman, J. (1998). Stuck. Sound Start Series.

Jackman, J. (1998). The new club hut. Sound Start Series.

Lewis, A. (1992). Group child interviews as a research tool. British Educational Research Journal, 18(4), 413-421.

Ministry of Education. (2002a). KBSR English language syllabus: Kuala Lumpur: Curriculum Development Centre.

Ministry of Education. (2002b). Revised English language curriculum: Orientation course for trainers and teachers. Kuala Lumpur: Curriculum Development Centre.

Penno, J. F., I.A.G. Wilkinson \& D.W. Moore. (2002). Vocabulary acquisition from teacher explanation and repeated listening to stories: Do they overcome the Matthew effect. Journal of Educational Psychology, 94(1), 23-33.

Richards, K. (2003). Qualitative inquiry in TESOL. Hampshire: Pelgrave Macmillan.

Rooks. (1998). Can I tell you my story? How storytelling contributes to pupils' achievements in other aspects of speaking and listening and to their understanding of how language works. Reading. UK Reading Association (UKRA).

Rosenhouse, J. D. Feitelson, B. Kita, \& Z. Goldstein. (1997). Interactive reading aloud to Israeli first graders: Its contribution to literacy development. Reading Research Quarterly, 32(2), 168-183.

Swann, J. (1994). Observing and recording talk in educational settings. In Graddol, D., Maybin, J., \& Stierer, B. (Eds.), Researching language and literacy in social context. Clevedon: Multilingual Matters.

Teale, W. H., \& Sulzby, E. (1987). Literacy acquisition in early childhood: The roles of access and mediation in storybook reading. In Wager, P.A. (Ed.), The future of literacy in a challenging world. New York: Pergamon Press.

Williams, A., \& Gregory, E. (1999). Home, school reading practices in two east end communities. In Tosi, A. \& Leung, C. (Eds.), Rethinking language and education from a monolingual to a multilingual perspectives. London: CILT. 
Yaacob, A. (2006). Malaysian literacy practices in English: Big books, CD-ROMs and the Year 1 English hour. Unpublished doctoral dissertation, University of Warwick, United Kingdom.

Yaden, D. B., Smolkin, L.B. \& Conlon, A. (1989). Preschoolers questions about pictures, print conventions, and story text during reading aloud at home. Reading Research Quarterly, Spring, 24 (2), 188-214. 